\title{
Improvement of Teacher Professional Competence by Teacher's Guide Book Making Learning Media
}

\author{
Arif Hartono ${ }^{1}$, Ristiana Dyah Purwandari² \\ $\left\{\underline{\text { arifnleksek@gmail.com }}{ }^{1}, \underline{\text { ristianadyah@yahoo.com }}{ }^{2}\right\}$ \\ ${ }^{1,2}$ Magister Pendidikan Dasar, Universitas Muhammadiyah Purwokerto \\ Jl KH Ahmad Dahlan, Banyumas 53182, Indonesia
}

\begin{abstract}
Manuals were not used by teachers in the creation of learning media. The purpose of this study is to see how the teacher's manual affects teachers' professional competence. The literature study method was used in this research. Making use of secondary data types. The collected data were analyzed and concluded in order to draw conclusions about the literature study. According to the research findings, literature studies from several research findings and journal articles show that the use of teacher manuals has an effect on increasing teacher professional competence.
\end{abstract}

Keywords: teacher's manual, teacher's professional competence, learning media

\section{Introduction}

In 2020 the government through the Regulation of the Minister of Education and Culture of the Republic of Indonesia Number 24 of 2020 issued the Affirmation BOS and Performance BOS. Affirmation BOS is a central government program allocated for primary and secondary education units in special areas. Meanwhile, BOS Performance is a fund allocated for schools that have good performance in providing education services in special areas determined by the ministry. The affirmation BOS and performance BOS in 2020 are focused on special areas and areas affected by the Covid-19 pandemic. From the results of interviews with schools receiving BOS affirmations and performance, most of it was spent to complete the facilities learning activities that have not been fulfilled from regular school operational assistance funds such as laptops and LCD projectors in the hope of improving the quality of learning.

Learning without a relevant lesson plan, a teacher will be stuck in the attitude of a preacher or lecturer that is monotonous, rigid, and boring. In order to overcome this, learning media is very much needed in an effort to overcome the limitations of space and time, for example objects that are too large, dangerous for students and difficult to obtain concrete forms can be replaced with pictures or models. Images that are too small can be enlarged using an LCD projector. In addition, learning media can also present events or events in the past through videos, such as volcanic eruptions.

The ideal teacher always improves his competence by innovating to achieve the targeted learning goals. The attachment of the Minister of National Education Number 16 of 2007 concerning Academic Qualification Standards and Teacher Competencies, regulates various competencies that must be possessed by educators, both core competencies and subject competencies. Teachers are required to carry out quality learning. Quality improvement in the learning process cannot be separated from the use of learning materials, strategies, and learning media. 
In learning activities, learning media are positioned as teaching aids so that the delivery of material becomes more easily accepted and makes learning activities more interesting for students because with the existence of learning media, the interaction or communication between teachers and students will be smoother. MMedia is anything that can convey and distribute messages from sources in a planned manner so as to create a conducive learning environment where the recipient can carry out the learning process efficiently and effectively [1].

In practice, not all teachers can create or develop learning media. The teacher's ability and knowledge in using a computer or laptop is minimal, making it difficult for teachers to innovate more. Educators, in this case, teachers who master the material have not been able to present a form of learning using computer as a learning medium.

Developing learning media that utilizes computers or laptops will provide a different atmosphere that can change the teacher's perception of learning media that has a good impact on teachers, because with a computer or laptop, teachers have the opportunity to develop learning media so that they can improve teacher competence for the better. Computers or laptops for teachers are expected to make it easier for them to create or develop learning media quickly and efficiently.

Efforts to increase these problems can be done one of them with a guide book.In everyday terms, manuals are often referred to as smart books because by reading this type of book people become as if they are smart about something they are doing, including something that was previously unclear. Other people also often refer to it as a handbook and a manual. A handbook is a compilation of various types of information that are compactly arranged and ready to use, specifically in a field such as a handbook of physics. While the manual (manual book) contains instructions, guidelines or procedures for doing something in stages [2]. The guide book in making learning media is expected to make it easier for teachers to develop learning media.

\section{Research methods}

This research is a literature review research. The data taken in this study is secondary data. Secondary data is data taken not from direct observers but from the results of research by previous researchers. The data collection method used in this research is the documentation method. The documentation method is a systematic data collection procedure for reviewing both printed and electronic documents [3]. The documentation method is a method of collecting data by searching for or digging data from the literature related to what is intended in the formulation of the problem. The data analysis used in this research is bibliographic annotation analysis. Annotation means a simple conclusion from an article, book, journal, or some other written source,

\section{Results and Discussion}

Based on the results of a study of several journal articles that teachers in Indonesia have difficulty in increasing their competence, they are taken from interviews and observations. The results of the interviews showed surprising results that most $(95 \%)$ of the teachers and their colleagues in East Java on average did not know how to implement cooperative learning approaches. The participants argued that those in the regions rarely received information about new innovations in their learning. They tend to use questions and answers, discussions and assignments only in their learning. Therefore, the trainees suggested to make a practical guidebook in implementing the cooperative learning model [5]. 
From the results of observations, interviews, and questionnaires, it can be concluded that elementary school students in Seririt sub-district have the opportunity to learn English from an early age even though it is only a local content. However, it is very unfortunate, because the educational background of the teachers who teach is not a bachelor of English education, these teachers still have problems in determining the materials and media for learning English. They need manuals that can guide them in choosing materials and media that are suitable for the character of their students. In connection with these findings, it is necessary to develop a manual that can help them with clear steps [4].

The research entitled "Development of Geogebra Guidebooks for Middle School Teachers on Building Materials during the COVID-19 Pandemic "The results show the development of the teacher's guidebook in this study, namely the validity test showing that the product is valid with a very high category, the product practicality test also shows that the product can be said to be practical. with a good category, and the product effectiveness test shows a good category so that the product has also been effective. In conclusion, the geogebra software guidebook product on building materials can be used by teachers to be able to help and support teaching activities in schools, especially during the Covid-19 pandemic [6].

The ideal teacher always improves his competence by innovating to achieve the targeted learning goals. Competence is a set of knowledge, skills, and behaviors that must be possessed, internalized, and mastered by teachers or lecturers in carrying out professional duties [7]. Based on Government Regulation No.74 of 2008 concerning Teachers, it is stated that the competencies that must be possessed by teachers include pedagogic competencies, professional personality competencies, and social competencies.

Competence is defined as the ability, then the competence of the tutor/teacher is the ability of a teacher or educator in carrying out their duties. Competence means authority, skill or ability. Here it is more appropriate if competence is defined by ability [8].

The attachment of the Minister of National Education Number 16 of 2007 concerning Academic Qualification Standards and Teacher Competencies, regulates various competencies that must be possessed by educators, both core competencies and subject competencies. Teachers are required to carry out quality learning. Quality improvement in the learning process cannot be separated from the use of learning materials, strategies, and learning media.

Professional competence includes expertise or expertise in their field, namely mastery of the material that must be taught along with the method, a sense of responsibility for their duties and a sense of togetherness with other teacher colleagues. Professional competence includes professional development, insightful understanding, and mastery of academic study materials. Professional development includes: (1) following information on science and technology developments that support the profession through various scientific activities, (2) translating textbooks/scientific works, (3) developing various learning models, (4) writing papers, (5) writing/compiling dictates lessons, (6) writing textbooks, (7) writing modules, (8) writing scientific papers, (9) conducting scientific research (action research), (10) finding appropriate technology, (11) making teaching aids/media, (12) creating works of art,

Teacher's Guidebook for Civics Learning in SD/MI through various cooperative learning models based on the basic concepts of cooperative learning and combined with needs to make it easier for teachers to teach Civics materials [10].

Learning resources are all sources in the form of data, people or objects that can be used to provide learning facilities for someone [8]. Based on a background study of several articles 
on the low competence of teachers, they used a solution to develop a teacher manual. The development of the teacher's manual is carried out with the hope that it can be used by teachers as a learning resource in order to improve their competence

With the guidebook, teachers no longer teach based on textbooks, but are able to create and modify their own teaching tools or teaching aids for teaching. By making their own learning tools or media, it can be said that teachers have innovative work that will have an impact on increasing their professional competence. In addition, with the availability of learning tools or media, the learning process will be more interesting and meaningful [11].

\section{Conclusion}

Teacher manuals affect the improvement of teachers' professional competence. Developing learning media by utilizing guidebooks and computers or laptops becomes easier and will provide a different atmosphere that can change the teacher's perception of learning media that has a good impact on teachers and students, because with a computer or laptop and teacher's manual the opportunity to develop learning media so that it can improve teacher competence to be better and more efficient and have a positive impact on the quality of learning which is followed by an increase in student achievement.

\section{References}

[1] Munadi Y. Media pembelajaran sebuah pendekatan baru. 2008.

[2] Sudarnoto AH. Pengantar Manajemen Perpustakaan Madrasah, Jakarta: UIN Syahid Jakarta. (2006)

[3] Bowen GA. Document analysis as a qualitative research method. Qualitative research journal, 2009.

[6] Arsyillah BT \& Muhid A. Pendidikan Multikultural Dalam Membentuk Karakter Pemuda Di Perguruan Tinggi. Al-Fikr: Jurnal Pendidikan Islam, 2020, 6.1: 17-26.

[7] Bachtiar D, Yudianto E \& Sugiarti, T. Pengembangan Buku Panduan Geogebra untuk Guru SMP Pada Materi Bangun Ruang di Masa Pandemi COVID-19. Jurnal Cendekia: Jurnal Pendidikan Matematika, 2021, 5.2: 1294-1307.. Jurnal Cendekia: Jurnal Pendidikan Matematika: Volume 5 Nomor 2, https://j-cup.org/index.php/cendekia/article/view/627

[8] Undang-undang Republik Indonesia Nomor 14 Tahun 2005, tentang Guru dan Dosen, Bandung: Penerbit Fokus Media.

[9] Daeng S. Kurikulum dan Pembelajaran Dalam Rangka Otonomi Daerah.Bandung: CV. Adira Bandung Warsita. 2002.

[10] Hanurawan F \& Soetjipto B E. Pengembangan buku panduan guru untuk pembelajaran PKn SD/MI melalui berbagai Model Cooperative Learning. Jurnal Sains Psikologi, 2018 , 1.2..http://journal2.um.ac.id/index.php/JSPsi/article/view/553/345

[11] Adnyani LDS; Mahayanti NWS; Suprianti, GAP. Pengembangan Buku Panduan Pembuatan Materi Dan Media Pembelajaran Bahasa Inggris Untuk Guru-Guru SD Di Kecamatan Seririt. In: SEMINAR NASIONAL RISET INOVATIF2017ISBN. 2017. p. 978-602. 